University of Wollongong

Research Online

Australian Institute for Innovative Materials -

Papers

Australian Institute for Innovative Materials

$1-1-2017$

\title{
Platinum-Cobalt Bimetallic Nanoparticles with Pt Skin for Electro-Oxidation of Ethanol
}

Binwei Zhang

University of Wollongong, Xiamen University, bz370@uowmail.edu.au

Tian Sheng

Xiamen University

Yunxiao Wang

University of Wollongong, yunxiao@uow.edu.au

Xi-Ming Qu

Xiamen University

Jun-Ming Zhang

Xiamen University

See next page for additional authors

Follow this and additional works at: https://ro.uow.edu.au/aiimpapers

Part of the Engineering Commons, and the Physical Sciences and Mathematics Commons

Research Online is the open access institutional repository for the University of Wollongong. For further information contact the UOW Library: research-pubs@uow.edu.au 


\title{
Platinum-Cobalt Bimetallic Nanoparticles with Pt Skin for Electro-Oxidation of Ethanol
}

\begin{abstract}
In order to maximize the Pt utilization in catalysts and improve catalytic processes, we report a convenient strategy for preparation of Pt3Co with Pt-skin structured bimetallic nanocatalysts directly supported on porous graphitic carbon. Notably, the thickness of the Pt-skin is only 1-2 atomic layers, about $0.5 \mathrm{~nm}$. Surprisingly, the bimetallic nanocatalysts composed of Pt3Co with Pt-skin are first used as ethanol electro-catalysts, with the mass activity of $0.79 \mathrm{~mA} i g \mathrm{gt}-1$, which is a $250 \%$ enhancement compared with commercial Pt/C $(0.32 \mathrm{~mA} i g \mathrm{gt}-1)$. On the basis of the results of electrochemical in situ Fourier transform infrared spectroscopy (FTIRS) and density functional theory (DFT), a new ethanol electro-oxidation enhancement mechanism is proposed in which Pt3Co with Pt-skin promotes partial oxidation of ethanol over $\mathrm{C}-\mathrm{C}$ bond cleavage, thereby resulting in higher $\mathrm{CH} 3 \mathrm{COOH}$ production than $\mathrm{CO} 2$ production.
\end{abstract}

\section{Keywords}

ethanol, bimetallic, electro-oxidation, nanoparticles, skin, pt, platinum-cobalt

Disciplines

Engineering | Physical Sciences and Mathematics

\section{Publication Details}

Zhang, B., Sheng, T., Wang, Y., Qu, X., Zhang, J., Zhang, Z., Liao, H., Zhu, F., Dou, S., Jiang, Y. \& Sun, S. (2017). Platinum-Cobalt Bimetallic Nanoparticles with Pt Skin for Electro-Oxidation of Ethanol. ACS Catalysis, 7 (1), 892-895.

\section{Authors}

Binwei Zhang, Tian Sheng, Yunxiao Wang, Xi-Ming Qu, Jun-Ming Zhang, Zong-Cheng Zhang, Hong-Gang Liao, Fu-Chun Zhu, Shi Xue Dou, Yan-Xia Jiang, and Shi-Gang Sun 


\title{
Platinum-Cobalt bimetallic nanoparticles with Pt skin for electro- oxidation of ethanol
}

\author{
Bin-Wei Zhang, ${ }^{\mathrm{a}, \mathrm{b}}$, Tian Sheng ${ }^{\mathrm{a}}$, Yun-Xiao Wang ${ }^{\mathrm{b}}$, Xi-Ming Qu ${ }^{\mathrm{a}}$, Jun-Ming Zhang ${ }^{\mathrm{a}}$, Zong-Cheng Zhang ${ }^{\mathrm{a}}$, \\ Hong-Gang Liao ${ }^{a}$, Fu-Chun Zhu ${ }^{a}$,Shi-Xue Dou ${ }^{\mathrm{b}}$, Yan-Xia Jiang ${ }^{\mathrm{a}, *}$ and Shi-Gang Sun ${ }^{\mathrm{a}, *}$ \\ a, State Key Laboratory of Physical Chemistry of Solid Surfaces, Department of Chemistry, College of Chemistry and Chem- \\ ical Engineering, Xiamen University, Xiamen 361005, China \\ b, Institute for Superconducting and Electronic Materials, Australian Institute of Innovative Materials, University of Wollon- \\ gong, Innovation Campus, Squires Way, North Wollongong, New South Wales 2500, Australia.
}

Supporting Information Placeholder

\begin{abstract}
In order to maximize the Pt utilization in catalysts and improve catalytic processes, we report a convenient strategy for preparation $\mathrm{Pt}_{3} \mathrm{Co}$ with Pt-skin structured bimetallic nanocatalysts directly supported on porous graphitic carbon. Notably, the thickness of the Pt-skin is only 1-2 atomic layers, about $0.5 \mathrm{~nm}$. Surprisingly, the bimetallic nanocatalysts composed of $\mathrm{Pt}_{3} \mathrm{Co}$ with Pt-skin are firstly used as ethanol electro-catalysts, with the mass activity of $0.79 \mathrm{~mA} \mu \mathrm{gPt}^{-1}$, which is $250 \%$ enhancement compared with commercial $\mathrm{Pt} / \mathrm{C}\left(0.32 \mathrm{~mA} \mu \mathrm{gPt}^{-1}\right)$. Based on the results of electrochemical in-situ Fourier transform infrared spectroscopy (FTIR) and density functional theory (DFT), a new ethanol electro-oxidation enhancement mechanism is proposed in which $\mathrm{Pt}_{3} \mathrm{Co}$ with Pt-skin promotes partial oxidation of ethanol over $\mathrm{C}-\mathrm{C}$ bond cleavage, thereby resulting in higher $\mathrm{CH}_{3} \mathrm{COOH}$ production than $\mathrm{CO}_{2}$ production.
\end{abstract}

Bimetallic nanoparticles play a vital role in energy conversion and storage, for instance supercapacitor, battery, fuel cell, and solar fuel ${ }^{1}$. Unlike monometallic nanoparticles, bimetallic nanoparticles ordinarily show better than the sum of its parts since them could create synergistic effect during them combination ${ }^{2}$. It is worth mentioning that electro-catalytic reactions only happen on electro-catalysts surface ${ }^{3}$. It is significant to investigate the surface composition of bimetallic catalysts thus a deeper understanding of electro-catalytic reaction mechanism, kinetics and energy efficiency would be produced.

Platinum equips with the attribute of excellent efficiency in electrocatalyst for ethanol electro-oxidation. Nevertheless, it is difficult to widely apply Pt in direct ethanol fuel cells (DEFCs) for both stationary and portable applications, since the barriers of the prices and scarcity of Pt. It is widely acknowledged that $\mathrm{CH}_{3} \mathrm{CH}_{2} \mathrm{OH}$ electro-oxidation involves two parallel pathways, the complete oxidation $\left(\mathrm{CH}_{3} \mathrm{CH}_{2} \mathrm{OH}+3 \mathrm{H}_{2} \mathrm{O}=2 \mathrm{CO}_{2}+12 \mathrm{H}^{+}+12 \mathrm{e}\right)$ and the incomplete oxidation $\left(\mathrm{CH}_{3} \mathrm{CH}_{2} \mathrm{OH}+\mathrm{H}_{2} \mathrm{O}=\mathrm{CH}_{3} \mathrm{COOH}+\right.$ $\left.4 \mathrm{H}^{+}+4 \mathrm{e}\right)$. In addition, $\mathrm{Pt}$ catalyst is inefficient at breaking the $\mathrm{C}$ $\mathrm{C}$ bond in ethanol oxidation. Considerable progress has been made towards improving ethanol electro-oxidation performance on Pt-based bimetallic electrocatalysts, such as alloying with $\mathrm{Pd}^{4}$, $\mathrm{SnO}_{2}{ }^{5}$, and $\mathrm{Rh}^{6}$. Meanwhile, atomic steps, ledges, and kinks were proven to play a significant role in ethanol electro-oxidation in our previous work ${ }^{7}$. And the $\mathrm{Pt}_{3} \mathrm{Ni}$ catalysts show different catalytic activity in terms of oxygen reduction reaction when the sur- face is tuned from Pt-skin to Ni-rich surface ${ }^{8}$. Since the atomic steps, ledges, and kinks of Pt-skin catalysts are different from those of pure $\mathrm{Pt}$ catalysts, we synthesized $\mathrm{Pt}_{3} \mathrm{Co}$ with a Pt-skin surface, supported on porous graphitic carbon (PC) (denoted as $\mathrm{Pt}_{3} \mathrm{Co} @ \mathrm{Pt} / \mathrm{PC}$ ). Pt and Co precursors were reduced by controlled thermal treatment, and the $\mathrm{Pt}_{3} \mathrm{Co}$ nanoparticles were welldispersed on PC, even after high temperature treatment (see Supporting Information). The reason of formation of Pt-skin may be following this: firstly, at $300{ }^{\circ} \mathrm{C}$ during $3 \mathrm{~h}$, platinum and cobalt precursors are reduced at forming gas (10 vol \% $\mathrm{H}_{2}$ in nitrogen), at this process platinum and cobalt precursors have been reduced. This process facilitates a surface segregation of Pt because it has a trend to form moderate segregation ${ }^{8}$. Further, while it was heated up to $700{ }^{\circ} \mathrm{C}$ for $3 \mathrm{~h}$, the segregation of $\mathrm{Pt}$ happened on the surface and the high temperature provides $\mathrm{H}_{2}$ enough energy to preferentially combine with $\mathrm{Pt}$ on the surface ${ }^{3 \mathrm{a}}$, which process is like high temperature process to form Pt-skin on single crystal ${ }^{3 c}$. This study is the first exploration of ethanol electro-oxidation on Ptskin of $\mathrm{Pt}_{3} \mathrm{Co} / \mathrm{PC}$, and it exhibited superior activity. Atomic resolution high-angle annular dark field (HAADF) scanning transmission electron microscope (STEM) imaging, coupled with electrochemical in-situ FTIR spectroscopy, are used to confirm the thickness of the Pt-skin is 1-2 atomic layers, about $0.5 \mathrm{~nm}$. In-situ FTIR and DFT give a new insight into breakage of the C-C bonds in ethanol on $\mathrm{Pt}_{3} \mathrm{Co} @ \mathrm{Pt} / \mathrm{PC}$ and $\mathrm{Pt} / \mathrm{C}$. In contrast to $\mathrm{Pt} / \mathrm{C}$, the Ptskin of $\mathrm{Pt}_{3} \mathrm{Co} @ \mathrm{Pt} / \mathrm{PC}$ is easier to produce acetic acid for ethanol electro-oxidation.

Figure 1a presents the atomic-resolution annular dark-field (ADF)-STEM image of $\mathrm{Pt}_{3} \mathrm{Co} @ \mathrm{Pt} / \mathrm{PC}$. It should be pointed out that the relationship between image's pixel intensity and the element number $\mathrm{Z}$ is the proportion on the whole in the HAADF imaging mode ${ }^{9}$, so compared with the Co columns, the Pt columns would show higher intensity, thus leading to higher Pt intensity than that of $\mathrm{Pt}_{3} \mathrm{Co}^{8}$. Therefore, we examined four sites of $\mathrm{Pt}_{3} \mathrm{Co} @ \mathrm{Pt} / \mathrm{PC}$. The intensities of the four sites in $\mathrm{Pt}_{3} \mathrm{Co} @ \mathrm{Pt} / \mathrm{PC}$ were determined by intensity analysis, which are shown in Figure 1b-e, respectively. Both sites L1 and L3 have $2 \mathrm{Pt}$ atomic layers; sites L2 and L4 have $1 \mathrm{Pt}$ atomic layer. As shown in the Figure $1 \mathrm{f}$ of the high-resolution TEM (HRTEM), the $d$-spacing of the edge is measured to be $2.27 \AA$, which is consistent with $\mathrm{Pt}(111)^{10}$, and the $d$-spacing of the center is $\sim 2.22 \AA$, which could correspond to $\mathrm{Pt}_{3} \mathrm{Co}(111)^{11}$. It indicates that the $\mathrm{Pt}_{3} \mathrm{Co} @ \mathrm{Pt} / \mathrm{PC}$ is Pt-skin surface; the center is $\mathrm{Pt}_{3} \mathrm{Co}$ alloy. An ADF-STEM image of a nanoparticle 
is showed in figure $2 \mathrm{a}$, which is spectroscopically imaged. The $\mathrm{Pt}$ element and Co element projected distributions in this particle in figure 2b-c. The composite image of $\mathrm{Pt}$ versus Co (Figure 2d) suggested that the surface of this nanoparticle contains more amount of Pt than Co. Furthermore, Figure 2e presents the corresponding line-profile analysis from figure $2 \mathrm{~d}$ shown by the arrow, which confirms that the thickness of Pt-skin is $\sim 0.5 \mathrm{~nm}$, corresponding to 2 atomic layers, consisting with the ADF results.
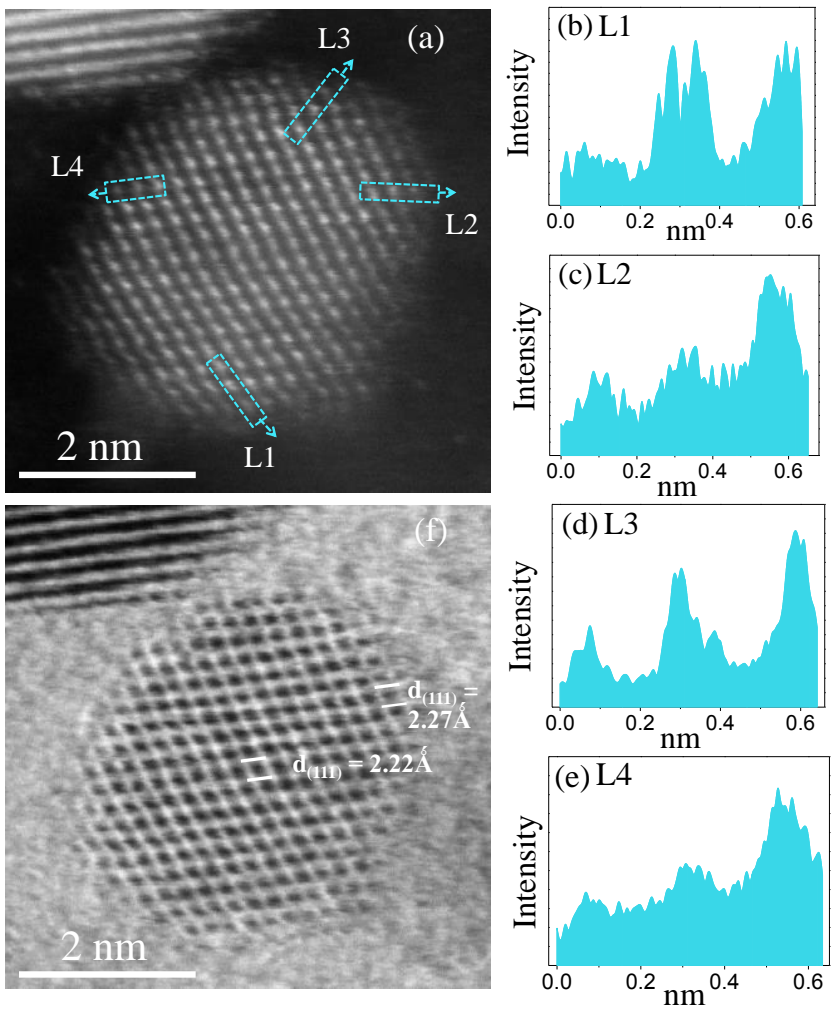

Figure 1(a) Atomic-resolution ADF-STEM image of $\mathrm{Pt}_{3} \mathrm{Co} @ \mathrm{Pt} / \mathrm{PC}$, with the intensity of sites L1, L2, L3, and L4 shown in (b)-(e); (f) HRTEM image of $\mathrm{Pt}_{3} \mathrm{Co} @ \mathrm{Pt} / \mathrm{PC}$.

The TEM image of $\mathrm{Pt}_{3} \mathrm{Co} @ \mathrm{Pt} / \mathrm{PC}$ (Figure S2a in the Supporting Information) clearly shows that the $\mathrm{Pt}_{3} \mathrm{Co} @ \mathrm{Pt}$ nanoparticles are well dispersed with a high loading on PC. The average diameter of $\mathrm{Pt}_{3} \mathrm{Co} @ \mathrm{Pt}$ nanoparticles (Figure S2b) is evaluated to be $3.06 \pm$ $0.86 \mathrm{~nm}$ from 200 nanoparticles. The X-ray diffraction (XRD) of $\mathrm{Pt}_{3} \mathrm{Co} @ \mathrm{Pt} / \mathrm{PC}$ and Pt/C (Johnson Matthey) are shown in figure S3. The broad peaks near $25^{\circ}$ of two catalysts are assigned to carbon; peaks at $40.3^{\circ}, 46.8^{\circ}, 68.2^{\circ}, 82.7^{\circ}$ of $\mathrm{Pt}_{3} \mathrm{Co} @ \mathrm{Pt} / \mathrm{PC}$ are agreement with that of $\mathrm{Pt} / \mathrm{C}$, which present $\mathrm{Pt}$ face-centered cubic (fcc) features. Compared to $\mathrm{Pt} / \mathrm{C}$, all broad diffraction peaks of $\mathrm{Pt}_{3} \mathrm{Co} @ \mathrm{Pt} / \mathrm{PC}$ are at high angles, because Co atoms are incorporated into the $\mathrm{Pt}$ fcc structure, forming $\mathrm{Pt}_{3} \mathrm{Co}$ alloy ${ }^{12}$.
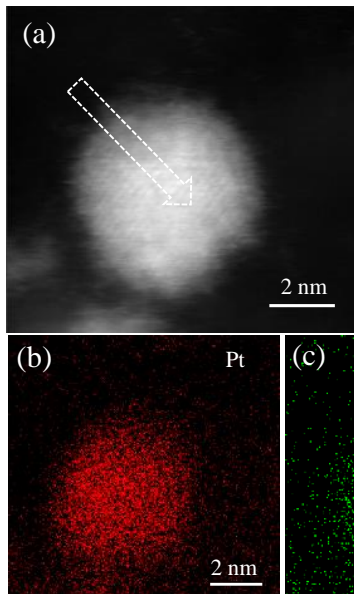
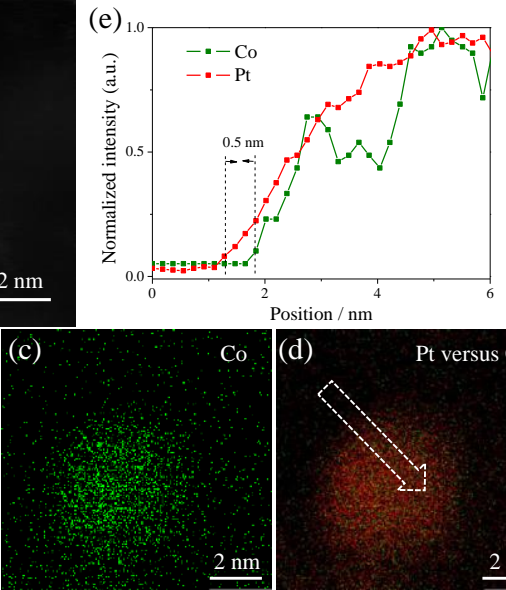
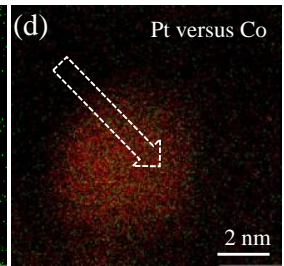

Figure 2(a) ADF-STEM image of $\mathrm{Pt}_{3} \mathrm{Co} @ \mathrm{Pt} / \mathrm{PC}$ nanoparticle. (b-d) 2D electron energy loss spectroscopic mapping of $\mathbf{P t}$ (red), Co (green), and the composite image of Pt vs Co. (e) Line-profile analysis from the indicated area of (a) and (d), demonstrating about $0.5 \mathrm{~nm}$ Pt skin thickness.

Cyclic voltammograms (CVs) of $\mathrm{Pt}_{3} \mathrm{Co} @ \mathrm{Pt} / \mathrm{PC}$ and $\mathrm{Pt} / \mathrm{C}$ are shown in Figure $\mathrm{S} 4 \mathrm{a}$, where the $\mathrm{Pt} / \mathrm{C}$ exhibits the well-known hydrogen adsorption and desorption of pure Pt nanoparticles dispersed on carbon black in $0.1 \mathrm{M} \mathrm{HClO}_{4}$ solution. In contrast, the $\mathrm{CV}$ of $\mathrm{Pt}_{3} \mathrm{Co} @ \mathrm{Pt} / \mathrm{PC}$ does not show any apparent hydrogen adsorption and desorption, which is probably because the presence of $\mathrm{Co}$ in the $\mathrm{Pt}{ }_{3} \mathrm{Co} @ \mathrm{Pt} / \mathrm{PC}$ results in reduced hydrogen adsorption and desorption capacity. $\mathrm{CO}_{\mathrm{ad}}$ stripping curves of two catalysts are shown in Figure $\mathrm{S} 4 \mathrm{~b}$. The ratio of integrated charges $\left(Q_{\mathrm{CO}} /\right.$ $\left.2 Q_{\mathrm{H}}\right)$ between $\mathrm{CO}$ stripping $\left(Q_{\mathrm{CO}}\right)$ and under potential deposition of hydrogen $H_{\text {upd }}\left(Q_{\mathrm{H}}\right)$ is calculated to be 1.54 and 1.10 for $\mathrm{Pt} @ \mathrm{Pt}_{3} \mathrm{Co} / \mathrm{PC}$ and $\mathrm{Pt} / \mathrm{C}$, respectively, in table $\mathrm{S} 2$. This relationship is in good agreement with the Pt-skin structure ${ }^{13}$.

On pure Pt, electro-oxidation of formic acid would form poisoning intermediates $\left(\mathrm{CO}_{\mathrm{ad}}\right)$ via "dual pathway" because the $\mathrm{CO}$ poisoning takes place on at least two consecutive Pt surface sites ${ }^{14}$. For $\mathrm{Pt}_{3} \mathrm{Co} @ \mathrm{Pt} / \mathrm{PC}$, the surface is $\mathrm{Pt}$; so $\mathrm{HCOOH}$ may form adsorbed $\mathrm{CO}\left(\mathrm{CO}_{\mathrm{ad}}\right)$ through the dual pathway mechanism on $\mathrm{Pt}_{3} \mathrm{Co} @ \mathrm{Pt} / \mathrm{PC}{ }^{8}$. Figure S5a shows the $\mathrm{CVs}$ of $\mathrm{Pt} / \mathrm{C}$ and $\mathrm{Pt}_{3} \mathrm{Co} @ \mathrm{Pt} / \mathrm{PC}$ in $0.1 \mathrm{M} \mathrm{HCOOH}+0.1 \mathrm{M} \mathrm{HClO}_{4}$ solution. The $\mathrm{Pt}_{3} \mathrm{Co} @ \mathrm{Pt} / \mathrm{PC}$ oxidation of $\mathrm{HCOOH}$ is similar to that of $\mathrm{Pt} / \mathrm{C}$, which also has two anodic peaks. This suggests that both $\mathrm{Pt}_{3} \mathrm{Co} / \mathrm{PC}$ (Pt-skin) and $\mathrm{Pt} / \mathrm{C}$ operate via the dual pathway mechanism poisoned by $\mathrm{CO}_{\mathrm{ad}}$. Electrochemical in-situ FTIR spectra of $\mathrm{HCOOH}$ oxidation are shown in Figure S5b and S5c. Reference spectrum potentials are collected at $-0.25 \mathrm{~V}$, and working spectrum potentials vary from -0.20 to $0.70 \mathrm{~V}(0.1 \mathrm{~V}$ interval $)$. The band at $2345 \mathrm{~cm}^{-1}$ is a characteristic peak of $\mathrm{CO}_{2}$ asymmetric stretching vibration that originates from direct $\mathrm{HCOOH}$ oxidized and $\mathrm{CO}_{\mathrm{ad}}$ oxidized, which can be observed in both catalysts. The band at $2050 \mathrm{~cm}^{-1}$ corresponds to linearly bonded $\mathrm{CO}\left(\mathrm{CO}_{\mathrm{L}}\right)$, which goes through the poisoning route. It is noteworthy that $\mathrm{CO} L$ could be found clearly for both $\mathrm{Pt}_{3} \mathrm{Co} @ \mathrm{Pt} / \mathrm{PC}$ and $\mathrm{Pt} / \mathrm{C}$, which indicates that oxidation of $\mathrm{HCOOH}$ via the poisoning route on $\mathrm{Pt}_{3} \mathrm{Co} @ \mathrm{Pt} / \mathrm{PC}$ as well. This conclusion furtherly implies that $\mathrm{Pt}_{3} \mathrm{Co} @ \mathrm{Pt} / \mathrm{PC}$ has a Pt-skin ${ }^{8}$. Moreover, the activity of $\mathrm{Pt}_{3} \mathrm{Co} @ \mathrm{Pt} / \mathrm{PC}$ is better than that of $\mathrm{Pt} / \mathrm{C}$; it attributes that the subsurface layers of Co atoms may affect the electronic structure of the outermost Pt-skin.
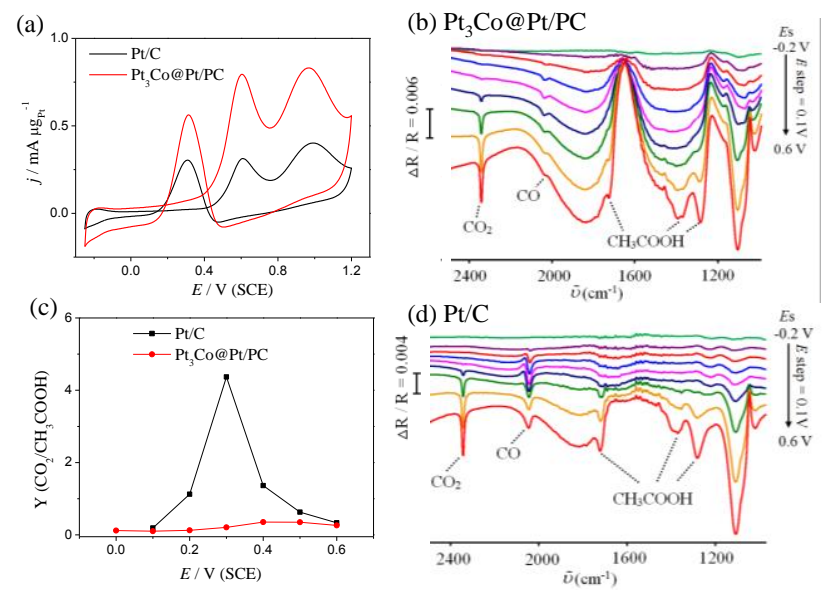

Figure 3(a) Cyclic voltammograms (CVs) of $\mathrm{Pt}_{3} \mathrm{Co} @ \mathrm{Pt} / \mathrm{PC}$ and $\mathrm{Pt} / \mathrm{C}$ in $0.1 \mathrm{M} \mathrm{CH} \mathrm{CH}_{2} \mathrm{OH}+0.1 \mathrm{M} \mathrm{HClO}_{4}$ solution, 50 $\mathrm{mV} \mathrm{s}^{-1}$. In-situ mass spectroscopy (MS) FTIR spectra of (b) 
$\mathrm{Pt}_{3} \mathrm{Co} @ \mathrm{Pt} / \mathrm{PC}$ and (d) $\mathrm{Pt} / \mathrm{C}$ for $\mathrm{CH}_{3} \mathrm{CH}_{2} \mathrm{OH}$ oxidation in $0.1 \mathrm{M}$ $\mathrm{CH}_{3} \mathrm{CH}_{2} \mathrm{OH}+0.1 \mathrm{M} \mathrm{HClO}_{4}$. (c) Ratio of integrated intensities of $\mathrm{CO}_{2}$ and intensities $\mathrm{CH}_{3} \mathrm{COOH}$ as a function of working potentials of the two electrocatalysts.

Electrocatalytic oxidation of ethanol in acidic solution $(0.1 \mathrm{M}$ $\mathrm{HClO}_{4}+0.1 \mathrm{M} \mathrm{CH}_{3} \mathrm{CH}_{2} \mathrm{OH}$ ) was used to study the catalytic property of the $\mathrm{Pt}_{3} \mathrm{Co} @ \mathrm{Pt} / \mathrm{PC}$, as shown in Figure 3a. It is obvious that $\mathrm{Pt}_{3} \mathrm{Co} @ \mathrm{Pt} / \mathrm{PC}$ and $\mathrm{Pt} / \mathrm{C}$ show similar $\mathrm{CV}$ curves, which display two peaks at $0.60 \mathrm{~V}$ and $0.96 \mathrm{~V}$, corresponding to the well-known ethanol electro-oxidation ${ }^{6 \mathrm{~b}}$. The first peak $($ at $0.60 \mathrm{~V})$ is ascribed to formation of $\mathrm{CH}_{3} \mathrm{CHO}, \mathrm{CH}_{3} \mathrm{COOH}$ and $\mathrm{CO}_{2}$; the following peak $\sim 0.96 \mathrm{~V}$ is assigned to $\mathrm{CH}_{3} \mathrm{COOH}$. Significantly, the current density of $\mathrm{Pt}_{3} \mathrm{Co} @ \mathrm{Pt} / \mathrm{PC}$ is $0.79 \mathrm{~mA} \mu \mathrm{gPt}^{-1}$ at $0.60 \mathrm{~V}$, which is 2.5 times as high as that of $\mathrm{Pt} / \mathrm{C}\left(0.32 \mathrm{~mA} \mu \mathrm{g}_{\mathrm{Pt}^{-1}}\right)$. Figure S6 shows the current-time cures at $0.45 \mathrm{~V}$ on $\mathrm{Pt}_{3} \mathrm{Co} @ \mathrm{Pt} / \mathrm{PC}$ and $\mathrm{Pt} / \mathrm{C}$ at room temperature. After $3600 \mathrm{~s}$, the activity of $\mathrm{Pt}_{3} \mathrm{Co} @ \mathrm{Pt} / \mathrm{PC}$ is still better than that of $\mathrm{Pt} / \mathrm{C}$, regardless of its mass activity or specific activity.

To understand the impact of the Pt-skin surface of $\mathrm{Pt}_{3} \mathrm{Co} @ \mathrm{Pt} / \mathrm{PC}$ electro-catalyst on ethanol, in-situ FTIR contributes to recognize the intermediate and final products to identify the selectivity towards $\mathrm{CH}_{3} \mathrm{CH}_{2} \mathrm{OH}$ electro-oxidation, as shown in Figure $3 \mathrm{~b}$ $\left(\mathrm{Pt}_{3} \mathrm{Co} @ \mathrm{Pt} / \mathrm{PC}\right)$ and $3 \mathrm{~d}(\mathrm{Pt} / \mathrm{C})$. The signature peak of $\mathrm{CO}_{2}(\sim 2345$ $\mathrm{cm}^{-1}$ ) corresponds to complete oxidation of $\mathrm{CH}_{3} \mathrm{CH}_{2} \mathrm{OH}$, which represents the breaking of the $\mathrm{C}-\mathrm{C}$ bond in $\mathrm{CH}_{3} \mathrm{CH}_{2} \mathrm{OH}$ oxidation. The band at $\sim 1720 \mathrm{~cm}^{-1}$ is attributed to the $\mathrm{C}=\mathrm{O}$ bond's stretching vibration in $\mathrm{CH}_{3} \mathrm{CHO}$ and $\mathrm{CH}_{3} \mathrm{COOH}$, which indicates incomplete electro-oxidation of $\mathrm{CH}_{3} \mathrm{CH}_{2} \mathrm{OH}$. The characteristic absorption band of $\mathrm{C}-\mathrm{O}$ stretching in $\mathrm{CH}_{3} \mathrm{COOH}$ at $1280 \mathrm{~cm}^{-1}$ is typically applied to quantitative analysis of $\mathrm{CH}_{3} \mathrm{COOH}$. Remarkably, lines for bound $\mathrm{CO}\left(\mathrm{CO}_{\mathrm{L}}\right)$ at $2050 \mathrm{~cm}^{-1}$ could be found in both the $\mathrm{Pt} / \mathrm{C}$ and the $\mathrm{Pt}_{3} \mathrm{Co} @ \mathrm{Pt} / \mathrm{PC}$ catalysts, which furtherly indicate that $\mathrm{Pt}_{3} \mathrm{Co} @ \mathrm{Pt} / \mathrm{PC}$ possesses a Pt skin. Figure S7 shows the variation of the integrated intensities of the $2345 \mathrm{~cm}^{-1}$ band $\left(\mathrm{CO}_{2}\right)$ and the $1280 \mathrm{~cm}^{-1}$ band $(\mathrm{C}-\mathrm{O})$ corresponding to potential for $\mathrm{Pt}_{3} \mathrm{Co} / \mathrm{PC}$ (Pt-skin) and commercial $\mathrm{Pt} / \mathrm{C}$ samples. To investigate the capability for $\mathrm{C}-\mathrm{C}$ bond breaking in $\mathrm{CH}_{3} \mathrm{CH}_{2} \mathrm{OH}$, we plot the ratio of integrated intensities $(I)$ associated with $\mathrm{CO}_{2}$ (total electooxidation) and $\mathrm{CH}_{3} \mathrm{COOH}$ (partial electro-oxidation) as a function of working potentials (Figure 3c). It can be clearly seen that the ratio of $I \mathrm{CO}_{2} / I_{\mathrm{CH}_{3} \mathrm{COOH}}$ firstly raises but reduces subsequently when the applied potentials increases. Compared with $\mathrm{Pt} / \mathrm{C}$, the value of $I \mathrm{CO}_{2} / I_{\mathrm{CH}_{3} \mathrm{COOH}}$ for $\mathrm{Pt}_{3} \mathrm{Co} @ \mathrm{Pt} / \mathrm{PC}$ is low, which suggests that the main product of $\mathrm{Pt}_{3} \mathrm{Co} @ \mathrm{Pt} / \mathrm{PC}$ is $\mathrm{CH}_{3} \mathrm{COOH}$. $\mathrm{Pt}$ is a poor catalyst for ethanol oxidation; adding $\mathrm{Sn}$ into $\mathrm{Pt}(\mathrm{PtSn})$ could ensemble electro-oxidize $\mathrm{CH}_{3} \mathrm{CH}_{2} \mathrm{OH}$ to $\mathrm{CH}_{3} \mathrm{COOH}$, which it is difficult to break the $\mathrm{C}-\mathrm{C}$ bond ${ }^{15}$. When $\mathrm{Sn}$ is added on the surface of $\mathrm{Pt}$, the alloy not only could minimize the poisoning effects but also improve the activity towards ethanol electro-oxidation ${ }^{15 a, 16}$. As for $\mathrm{Sn}$, it could increase formation of $\mathrm{OH}$ species at lower potential, which could oxidize $\mathrm{CH}_{3} \mathrm{CHO}$ to produce more $\mathrm{CH}_{3} \mathrm{COOH}^{15}$. The comparison $\mathrm{Pt}_{3} \mathrm{Co} @ \mathrm{Pt} / \mathrm{PC}$ with Pt-Sn catalyst is listed in table S3. It could be found that specific activity of $\mathrm{Pt}_{3} \mathrm{Co} @ \mathrm{Pt} / \mathrm{PC}$ at $0.3 \mathrm{~V}$ is lower than $\mathrm{PtSn}^{15 \mathrm{~b}}$ and $\mathrm{Pt}_{7} \mathrm{Sn}_{3}{ }^{17}$. It may be attributed that the surface of $\mathrm{Pt}_{3} \mathrm{Co} @ \mathrm{Pt} / \mathrm{PC}$ is Pt-skin, however, the surface of $\mathrm{PtSn}^{15 b}$ and $\mathrm{Pt}_{7} \mathrm{Sn}_{3}{ }^{17}$ have $\mathrm{Sn}$, which help formation of $\mathrm{OH}$ species.

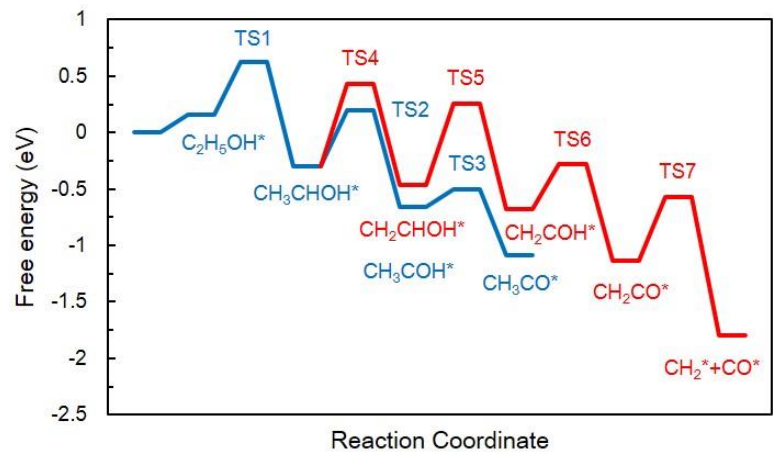

Figure 4 Energy profiles of ethanol electrooxidation on the stepped $\mathrm{Pt}_{3} \mathrm{Co}(211)$ surface.

The reaction mechanism of $\mathrm{CH}_{3} \mathrm{CH}_{2} \mathrm{OH}$ electro-oxidation on the stepped $\mathrm{Pt}_{3} \mathrm{Co}(211)$ surface with a Pt-skin structure were revealed by DFT calculations. The free energy is displayed in Figure 4 and all the calculated data and the optimized structures are shown in Figure S8 and S9. According to the previous theoretical investigation, $\mathrm{CH}_{3} \mathrm{CHOH}^{*}$ can break the $\alpha-\mathrm{C}-\mathrm{H}$ bond or the $\beta-\mathrm{C}-\mathrm{H}$ bond, and the barrier difference between them can be used to evaluate the $\mathrm{CH}_{3} \mathrm{COOH} / \mathrm{CO}_{2}$ selectivity ${ }^{18}$. On stepped $\mathrm{Pt}_{3} \mathrm{Co}(211)$ surface, $\mathrm{CH}_{3} \mathrm{CHOH}^{*}$ strongly prefers to break the $\alpha-\mathrm{C}-\mathrm{H}$ bond, producing $\mathrm{CH}_{3} \mathrm{COH}^{*}$ with a barrier being $0.5 \mathrm{eV}$ (transition state(TS) 2,) rather than breaking the $\beta-\mathrm{C}-\mathrm{H}$ bond with a barrier being $0.73 \mathrm{eV}$ (TS 4). Afterwards, $\mathrm{CH}_{3} \mathrm{CO}^{*}$ readily forms after overcoming a barrier of $0.16 \mathrm{eV}$ to break the $\mathrm{O}-\mathrm{H}$ bond in $\mathrm{CH}_{3} \mathrm{COH}^{*}$ (red line). $\mathrm{CH}_{3} \mathrm{CO}^{*}$ is rather stable on the surface and would be oxidized to $\mathrm{CH}_{3} \mathrm{COOH}^{*}$ at high potentials, leading the partial electrooxidation of $\mathrm{CH}_{3} \mathrm{CH}_{2} \mathrm{OH}$ to $\mathrm{CH}_{3} \mathrm{COOH}$ dominated, which is in consistent with the in situ FTIR observations. In the other way to break $\mathrm{C}-\mathrm{C}$ bond starting from $\mathrm{CH}_{2} \mathrm{CHOH}^{*}$, the $\mathrm{C}-\mathrm{H}$ bond breaking barrier is $0.72 \mathrm{eV}$ to yield $\mathrm{CH}_{2} \mathrm{COH}^{*}$, and the $\mathrm{O}-\mathrm{H}$ bond breaking barrier is $0.4 \mathrm{eV}$ for the formation of $\mathrm{CH}_{2} \mathrm{CO}^{*}$. $\mathrm{CH}_{2} \mathrm{CO}^{*}$ is a reasonable precursor to split the $\mathrm{C}-\mathrm{C}$ bond to $\mathrm{CH}_{2} *$ and $\mathrm{CO} *$ with a low barrier of $0.57 \mathrm{eV}$ (blue line).

In summary, the $\mathrm{Pt}_{3} \mathrm{Co} @ \mathrm{Pt} / \mathrm{PC}$ with the Pt-skin structure was successfully prepared by a sample controlled thermal treatment method. A unique Pt-skin structure is confirmed by a series of complementary techniques. The Pt-skin is 1-2 atomic layers with thickness of about $0.5 \mathrm{~nm}$. Benefiting from the bimetallic synergetic effect and unique structural advantages, the mass activity of $0.79 \mathrm{~mA} \mu \mathrm{gPt}^{-1}$ is achieved on $\mathrm{Pt}_{3} \mathrm{Co} @ \mathrm{Pt} / \mathrm{PC}$, which is 2.5 times as high as that of $\mathrm{Pt} / \mathrm{C}$ towards ethanol electro-oxidation. Via in-situ FTIR spectra and DFT, ethanol prefers to be broken $\alpha-\mathrm{C}-\mathrm{H}$ bond producing $\mathrm{CH}_{3} \mathrm{COH}^{*}$ rather than breaking the $\beta-\mathrm{C}-\mathrm{H}$ bond yielding $\mathrm{CH}_{2} \mathrm{COH}^{*}$ on $\mathrm{Pt}_{3} \mathrm{Co} @ \mathrm{Pt} / \mathrm{PC}$.

\section{ASSOCIATED CONTENT}

\section{Supporting Information}

Experimental details, related characterization, and supporting results and discussion. This material is available free of charge via the Internet at http://pubs.acs.org.

\section{AUTHOR INFORMATION}

\section{Corresponding Author}

yxjiang@xmu.edu.cn and sgsun@xmu.edu.cn 


\section{ACKNOWLEDGMENT}

This work was supported by the National Natural Science Foundation of China (Grant Nos. 21273180, 21321062, 21361140374, 2015CB932303, 51421002, XDB07030200, 2014CB921002, and 51522212). The authors also acknowledge Dr.Tania Silver for her critical reading.

\section{REFERENCES}

[1] a) E. E. Benson, C. P. Kubiak, A. J. Sathrum, J. M. Smieja, Chem Soc Rev 2009, 38, 89-99; b) M. Sankar, N. Dimitratos, P. J. Miedziak, P. P. Wells, C. J. Kiely, G. J. Hutchings, Chem Soc Rev 2012, 41, 8099-8139; c) M. R. Gao, Y. F. Xu, J. Jiang, S. H. Yu, Chem Soc Rev 2013, 42, 2986-3017.

[2] a) D. Wang, Y. Yu, H. L. Xin, R. Hovden, P. Ercius, J. A. Mundy, H. Chen, J. H. Richard, D. A. Muller, F. J. DiSalvo, H. D. Abruña, Nano Letters 2012, 12, 5230-5238; b) C. Wang, N. M. Markovic, V. R. Stamenkovic, ACS Catalysis 2012, 2, 891-898.

[3] a) H. Liao, A. Fisher, Z. J. Xu, Small 2015, 11, 3221-3246; b) D. Volpe, E. Casado-Rivera, L. Alden, C. Lind, K. Hagerdon, C. Downie, C. Korzeniewski, F. J. DiSalvo, H. D. Abruña, Journal of The Electrochemical Society 2004, 151, A971; c) V. R. Stamenkovic, B. Fowler, B. S. Mun, G. F. Wang, P. N. Ross, C. A. Lucas, N. M. Markovic, Science 2007, 315, 493-497.

[4] a) C. Zhu, S. Guo, S. Dong, Advanced Materials 2012, 24, 2326-2331; b) K. Sasaki, H. Naohara, Y. Cai, Y. M. Choi, P. Liu, M. B. Vukmirovic, J. X. Wang, R. R. Adzic, Angewandte Chemie, International Edition 2010, 49, 86028607.

[5] W. Du, G. Yang, E. Wong, N. A. Deskins, A. I. Frenkel, D. Su, X. Teng, J Am Chem Soc 2014, 136, 10862-10865.

[6] a) A. Kowal, M. Li, M. Shao, K. Sasaki, M. B. Vukmirovic, J. Zhang, N. S. Marinkovic, P. Liu, A. I. Frenkel, R. R. Adzic, Nature Materials 2009, 8 325; b) L. Rao, Y.-X. Jiang, B.-W. Zhang, Y.-R. Cai, S.-G. Sun, Physical Chemistry Chemical Physics 2014, 16, 13662.

[7] N. Tian, Z.-Y. Zhou, S.-G. Sun, Y. Ding, Z. L. Wang, Science 2007, 316, 732-735.

[8] B.-W. Zhang, Z.-C. Zhang, H.-G. Liao, Y. Gong, L. Gu, X.M. Qu, L.-X. You, S. Liu, L. Huang, X.-C. Tian, R. Huang, F.-C. Zhu, T. Liu, Y.-X. Jiang, Z.-Y. Zhou, S.-G. Sun, Nano Energy 2016, 19, 198-209.

[9] S. J. Pennycook, D. E. Jesson, Ultramicroscopy 1991, 37, 14-38.

[10] S.-I. Choi, S. Xie, M. Shao, J. H. Odell, N. Lu, H.-C. Peng, L. Protsailo, S. Guerrero, J. Park, X. Xia, J. Wang, M. J. Kim, Y. Xia, Nano Letters 2013, 13, 3420-3425.

[11] S. I. Choi, R. Choi, S. W. Han, J. T. Park, Chemistry 2011 , 17, 12280-12284.

[12] D. Wang, H. L. Xin, R. Hovden, H. Wang, Y. Yu, D. A. Muller, F. J. DiSalvo, H. D. Abruña, Nat Mater 2013, 12, 81-87.

[13] a) D. F. van der Vliet, C. Wang, D. Li, A. P. Paulikas, J. Greeley, R. B. Rankin, D. Strmcnik, D. Tripkovic, N. M. Markovic, V. R. Stamenkovic, Angewandte Chemie, International Edition 2012, 51, 3139-3142; b) C. Chen, Y. J. Kang, Z. Y. Huo, Z. W. Zhu, W. Y. Huang, H. L. L. Xin, J. D. Snyder, D. G. Li, J. A. Herron, M. Mavrikakis, M. F. Chi, K. L. More, Y. D. Li, N. M. Markovic, G. A. Somorjai, P. D. Yang, V. R. Stamenkovic, Science 2014, 343, 1339-1343.

[14] a) S. Park, Y. Xie, M. J. Weaver, Langmuir 2002, 18, 57925798 ; b) E. Leiva, T. Iwasita, E. Herrero, J. M. Feliu, Langmuir 1997, 13, 6287-6293.

[15] a) Q. Wang, G. Q. Sun, L. H. Jiang, Q. Xin, S. G. Sun, Y. X. Jiang, S. P. Chen, Z. Jusys, R. J. Behm, Physical chemistry chemical physics $P$ 2007, 9, 2686-2696; b) L. Rao, B.W. Zhang, Y. Y. Li, Y. X. Jiang, S. G. Sun, Journal of Electrochemistry, 2014, 20, 395-400.

[16] a) V. Del Colle, J. Souza-Garcia, G. Tremiliosi-Filho, E. Herrero, J. M. Feliu, Physical chemistry chemical physics 2011, 13, 12163-72; b) L. Jiang, L. Colmenares, Z. Jusys, G. Q. Sun, R. J. Behm, Electrochim. Acta 2007, 53 (2), 377 389.

[17] W. Du, G. Yang, E. Wong, N. A. Deskins, A. I. Frenkel, D. Su, X. Teng, J Am Chem Soc 2014, 136, 10862-5.

[18] a) T. Sheng, W. F. Lin, C. Hardacre, P. Hu, Phys. Chem. Chem. Phys., 2014, 16, 13248-13254; b) T. Sheng, W. F. Lin, S. G. Sun, Phys. Chem. Chem. Phys., 2016, 18, 1550115504. 
2-D S nanosheets were successfully in-situ grew on $\mathrm{Cu}$ foam current collector. When applied as cathode for room roomtemperature Na-S batteries, the $\mathrm{S}$ cathode delivers ultrahigh electroactivity with the highest initial discharge/charge capacity of 3189/1403 mAh g-1 , which shows great potential to realize high-capacity S cathode.

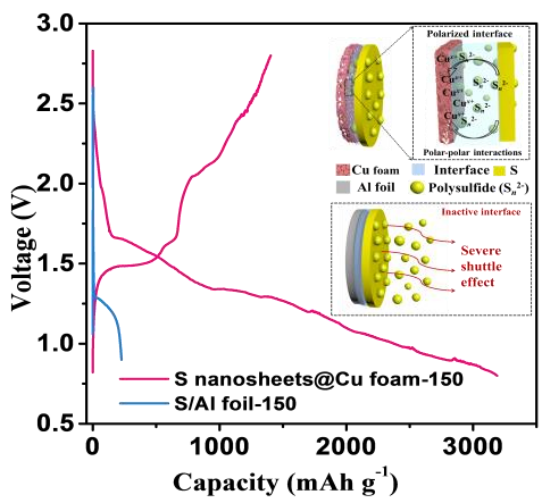

